DOI: $10.19195 / 2300-7729.37 .3$

\title{
Zmiany w zasadach realizacji zadań w Bibliotece Głównej Uniwersytetu Ekonomicznego we Wrocławiu w latach 1947-2016
}

\section{Wstęp}

Biblioteka Główna Uniwersytetu Ekonomicznego we Wrocławiu jako biblioteka akademicka zaliczana jest do grupy bibliotek naukowych. Zadania biblioteki naukowej definiowane są w aktach prawnych, takich jak ustawy o bibliotekach i o szkolnictwie wyższym. W 1952 roku ukazał się Wzorcowy statut szkoły wyższej, który określał zadania bibliotek uczelni wyższych. Wśród nich brak było jeszcze zadań dydaktycznych i informacyjnych ${ }^{1}$, ale już Ustawa $\mathrm{z}$ dnia 5 listopada 1958 roku o szkołach wyższych doprecyzowała miejsce, rolę i podstawowe zadania bibliotek szkół wyższych, które przez długie lata pozostały aktualne: „Szkoła wyższa posiada bibliotekę główną, która jest ogólnouczelnianym zakładem o zadaniach naukowych, dydaktycznych i usługowych oraz ma charakter publicznej biblioteki naukowej"2. Ustawa z dnia 9 kwietnia 1968 roku o bibliotekach wprowadziła zapis o konieczności prowadzenia przez biblioteki prac informacyjnych $^{3}$, a Ustawa o szkolnictwie wyższym z 4 maja 1982 roku o pełnieniu przez nie funkcji ośrodka informacji naukowej ${ }^{4}$. Kolejne ustawy nie zmieniły w sposób zasadniczy podstawowych zadań biblioteki akademickiej ${ }^{5}$.

${ }^{1}$ Uchwała nr 447 Rady Ministrów z dnia 4 czerwca 1952 roku w sprawie wzorcowego statutu szkoły wyższej, M.P. 1952, nr 57, poz. 883, par. 42.

${ }^{2}$ Ustawa z dnia 5 listopada 1958 roku o szkołach wyższych, Dz.U. 1958, nr 68, poz. 336, art. 14 , pkt 1 .

3 Ustawa z dnia 9 kwietnia 1968 roku o bibliotekach, Dz.U. 1968, nr 12, poz. 63, art. 17, pkt 2.

4 Ustawa z dnia 4 maja 1982 roku o szkolnictwie wyższym, Dz.U. 1982, nr 14, poz. 113, art. 32 , pkt 1 .

5 Ustawa z dnia 12 września 1990 roku o szkolnictwie wyższym, Dz.U. 1990, nr 65, poz. 385, art. 65 , pkt 1 . 
Niniejszy artykuł poświęcony będzie realizacji podstawowych zadań w Bibliotece Głównej Uniwersytetu Ekonomicznego we Wrocławiu w pięciu różnych okresach rozwoju placówki od chwili jej powstania do 2016 roku:

1. Początki tworzenia Uczelni i Biblioteki (1947-1964).

2. Rozwój usług informacyjnych (1965-1989).

3. Transformacja ustrojowa i gospodarcza. Komputeryzacja Biblioteki (19902005).

4. Budowa nowego gmachu (2006-2010).

5. W nowym budynku (2011-2016).

\section{Początki tworzenia Uczelni i Biblioteki (1947-1964)}

3 lutego 1947 roku rozpoczęła działalność Wyższa Szkoła Handlowa we Wrocławiu ${ }^{6}$. Jednocześnie powstała biblioteka, włączając się w realizację procesu naukowego i dydaktycznego uczelni.

\section{Zadania usługowe}

W pierwszych latach istnienia (1947-1954) Biblioteka koncentrowała się przede wszystkim na organizacji warsztatu naukowego, czyli gromadzeniu, opracowaniu i udostępnianiu zbiorów. Księgozbiór należało stale dostosowywać do często zmieniającego się programu nauczania (uwzględniając między innymi przedmioty indoktrynacyjne, utworzenie Wydziału Inżynieryjno-Ekonomicznego Przemysłu Rolno-Spożywczego) ${ }^{7}$. Opracowanie formalne zbiorów odbywało się według Skróconych przepisów katalogowania alfabetycznego, opracowanych przez Józefa Grycza i Władysławę Borkowską (Warszawa 1949). W zakresie opracowania rzeczowego zdecydowano się na wybór katalogu systematycznego wzorowanego na klasyfikacji „Przewodnika Bibliograficznego”. Udostępnianie zbiorów odbywało się prezencyjnie. Początkowo Biblioteka zajmowała dwie sale o powierzchni $30 \mathrm{~m}^{2}$, w tym czytelnię na trzydzieści miejsc, a od 1949 roku obejmowała powierzchnię $372 \mathrm{~m}^{2}$, w tym czytelnię na sto cztery miejsca. Poprawa warunków lokalowych nastąpiła w 1954 roku, kiedy Uczelnię i Bibliotekę przeniesiono do budynków przy ulicy Komandorskiej 118/120. Powierzchnia Biblioteki wynosiła $1700 \mathrm{~m}^{2}$. Zwiększyła się liczba miejsc w czytelniach (dziewięćdziesiąt

${ }^{6}$ Uczelnia kilkakrotnie zmieniała nazwę — w 1950 na: Wyższa Szkoła Ekonomiczna, w 1974 na: Akademia Ekonomiczna im. Oskara Langego, w 2008 na: Uniwersytet Ekonomiczny — Uniwersytet Ekonomiczny we Wrocławiu, http://www.ue.wroc.pl/uczelnia/40/historia uczelni.html [dostęp: 5.02.2018].

${ }^{7}$ Ksiega 60-lecia Akademii Ekonomicznej im. Oskara Langego we Wrocławiu, red. J. Chumiński, Wrocław 2007, s. 47, 163. 
osiem w ogólnej, pięćdziesiąt siedem w czytelni czasopism i osiem w czytelni dla pracowników nauki). Rozpoczęła działalność wypożyczalnia. W 1962 roku powstał Oddział Informacji Naukowej, który prowadził zajęcia z informacji naukowej, sprawował nadzór nad bibliotekami zakładowymi, a w 1964 roku wydał Bibliografię publikacji pracowników nauki Wyższej Szkoły Ekonomicznej we Wroclawiu za lata 1950-1962 autorstwa Jolanty Marcinkowskiej i Haliny Pabisz, opublikowaną w „Zeszytach Naukowych Wyższej Szkoły Ekonomicznej we Wrocławiu". W 1964 roku w skład struktury organizacyjnej Biblioteki wchodziły:

- Oddział Gromadzenia i Uzupełniania Zbiorów,

- Oddział Opracowania Zbiorów,

- Oddział Udostępniania Zbiorów,

— Oddział Informacji Naukowej,

- Pracownia fototechniczna ${ }^{8}$.

\section{Zadania dydaktyczne}

Biblioteka rozpoczęła prowadzenie zajęć bibliotecznych w roku akademickim 1953/1954. Początkowo był to ośmiogodzinny wykład dla studentów pierwszego roku w celu zapoznania ich z funkcjonowaniem Biblioteki, jej zbiorami, regulaminami oraz z udostępnianymi materiałami bibliograficznymi. Z czasem wprowadzono nowe przedmioty, podczas których bibliotekarze udzielali wskazówek w zakresie organizowania pracy naukowo-badawczej, zbierania materiałów do pisania artykułów, prac magisterskich czy doktorskich. Do 1964 roku prowadzone były następujące przedmioty:

1. Przysposobienie biblioteczne — dla studentów pierwszego roku studiów stacjonarnych i zaocznych (jednorazowe zajęcia dwugodzinne).

2. Technologia pracy umysłowej - dla studentów trzeciego roku (jednorazowy dwugodzinny wykład).

3. Informacja naukowa - dla studentów trzeciego roku oraz pomocniczych pracowników nauki (jeden dwugodzinny wykład i osiem godzin ćwiczeń w grupach).

4. Przysposobienie edytorskie - dla pomocniczych pracowników nauki (sześć godzin wykładu) ${ }^{9}$.

8 A. Kudelski, Biblioteka Główna Wyższej Szkoły Ekonomicznej we Wrocławiu, [w:] Zarys rozwoju wrocławskiej Wyższej Szkoty Ekonomicznej w latach 1946-1964, red. Z. Hellwig, Wrocław 1965, s. 115-116, 119, 122.

9 B. Chrapczyńska, M. Świrad, Edukacja informacyjna w bibliotece akademickiej, [w:] Biblioteka na miarę: przestrzeń, zasoby, usługi, red. M. Świrad, B. Żmigrodzka, Wrocław 2016, s. 160 . 


\section{Zadania naukowe}

Od 1954 roku bibliotekarze włączyli się w realizację zadań naukowych. Pierwszą publikacją był artykuł Kazimierza Sołtysika $W$ sprawie nauczania ogólnych zasad bibliotekarskich w wyższych szkołach ekonomicznych (,Ż̇ycie Szkoły Wyższej” 1954, nr 6). Był on jednym z głosów w dyskusji na temat konieczności prowadzenia zajęć bibliotecznych przez bibliotekarzy na wyższych uczelniach. Od 1957 roku bibliotekarze regularnie uczestniczyli w konferencjach bibliotek uczelni ekonomicznych. W 1960 roku Biblioteka zorganizowała we Wrocławiu Ogólnopolską Konferencję Bibliotek Wyższych Szkół Ekonomicznych na temat gromadzenia zbiorów oraz sytuacji lokalowej bibliotek ekonomicznych. Wilhelm Michniewicz wygłosił podczas niej referat Gromadzenie i uzupetnianie zbiorów w bibliotekach wyższych szkót ekonomicznych wedtug stanu na dzień 31 XII 1959 r., a Kazimierz Sołtysik — Sytuacja lokalowa bibliotek wyższych szkó ekonomicznych wedlug stanu na dzień 31 XII 1959 r. Oba teksty ukazały się w „Rocznikach Bibliotecznych" z 1962 roku (z. 1-2) ${ }^{10}$. Wraz z organizacją w bibliotekach oddziałów informacji naukowej powstał artykuł autorstwa Haliny Pabisz Uwagi w sprawie oddziatów informacji naukowej w bibliotekach szkót wyższych, opublikowany w „Przeglądzie Bibliotecznym” z 1964 roku (z. 4). Działalność Biblioteki oraz innych bibliotek wyższych szkół ekonomicznych w okresie powojennym podsumował Aleksander Kudelski w pracach: Biblioteka Główna Wyższej Szkoty Ekonomicznej we Wrocławiu (jeden z rozdziałów w pracy Zarys rozwoju wrocławskiej Wyższej Szkoły Ekonomicznej w latach 1946-1964, Wrocław 1965) oraz Materiaty do kroniki bibliotek wyższych szkót ekonomicznych za lata 1945-1963 (,Roczniki Biblioteczne” 1964, z. 1-2) ${ }^{11}$.

Tematyka publikacji dotyczyła problemów, które szczególnie zajmowały nowo powstałe biblioteki uczelni ekonomicznych: tworzenie księgozbioru, warunki lokalowe i związane z nimi udostępnianie zbiorów, początki działalności informacyjnej, dydaktyka biblioteczna.

10 A. Kudelski, Materiaty do kroniki bibliotek wyższych szkół ekonomicznych za lata 19451963, „Roczniki Biblioteczne” 1964, z. 1-2, s. 320, 323.

11 J. Kasprzyk-Machata, M. Zgorzelska, Publikacje pracowników Biblioteki Głównej Uniwersytetu Ekonomicznego we Wrocławiu, [w:] Dolnoślaskie Centrum Informacji Naukowej i Ekonomicznej - biblioteka otwarta, red. B. Żmigrodzka, Wrocław 2011, s. 198, 201-202. 


\section{Rozwój usług informacyjnych (1965-1989)}

\section{Zadania usługowe}

W związku z powołaniem w 1976 roku Wydziału Zarządzania i Informatyki ${ }^{12}$ nastąpił w Bibliotece wzrost liczby zbiorów i rozszerzył się profil gromadzonej literatury. Spowodowało to zmiany w strukturze organizacyjnej i w opracowaniu rzeczowym zbiorów. W 1978 roku zlikwidowano Oddział Opracowania Zbiorów i utworzono Oddział Opracowania Alfabetycznego Zbiorów oraz Oddział Opracowania Rzeczowego Zbiorów. Oddział Opracowania Rzeczowego Zbiorów prowadził katalog systematyczny jeszcze do 1985 roku, ale już od 1980 roku rozpoczął prowadzenie katalogu przedmiotowego ${ }^{13}$. Oddział Opracowania Alfabetycznego Zbiorów od 1984 roku rozpoczął opracowanie zbiorów według Przepisów katalogowania ksiażek. Cz. 1. Opis bibliograficzny, opracowanych przez Marię Lenartowicz (Warszawa 1984). Wraz ze wzrostem liczby czytelników Oddział Udostępniania zwiększył liczbę miejsc w czytelni ogólnej do stu trzydziestu dwóch ${ }^{14}$. Rozwinął swe usługi Oddział Informacji Naukowej. Najważniejsze z nich to:

— tworzenie kartotek zagadnieniowych (dotyczących między innymi EWG, Oskara Langego, Wincentego Stysia, Nagrody Nobla z dziedziny ekonomii),

— prowadzenie działalności wydawniczej (bibliografie publikacji pracowników Uczelni, informatory o Bibliotece, wykazy nabytków),

— organizacja wystaw książek,

— organizacja dydaktyki bibliotecznej,

- współpraca z bibliotekami naukowymi zgodnie z planem Systemu Informacji Naukowej, Technicznej i Organizacyjnej (SINTO),

— zapoczątkowanie (we współpracy z Instytutem Informatyki Akademii Ekonomicznej) procesów automatyzacji i komputeryzacji przez wdrożenie Systemu Wyszukiwania Informacji Naukowo-Technicznej WINT obejmującego znajdujące się w zbiorach Biblioteki druki zwarte z zakresu informatyki oraz systemu ASIB (Automatyczny System Informacji Bibliograficznej) opracowanego na bazie systemu OZAGA (Organizacja, Zarządzanie, Administracja, Gospodarka) ${ }^{15}$.

12 Księga 60-lecia Akademii Ekonomicznej im. Oskara Langego we Wrocławiu..., s. 192.

13 U. Żmijewska, Opracowanie rzeczowe zbiorów, [w:] Ewolucja procesów bibliotecznych na tle dziejów Biblioteki Głównej Akademii Ekonomicznej we Wrocławiu, red. B. Żmigrodzka, Wrocław 2007, s. 90.

14 E. Zagrajek, B. Żmigrodzka, Biblioteka Główna 1947-1982, Wrocław 1983, s. 19.

15 B. Tichy, Ustugi Oddziału Informacji Naukowej w latach 1962-2006, [w:] Ewolucja procesów bibliotecznych na tle dziejów Biblioteki Głównej Akademii Ekonomicznej we Wrocławiu..., s. $162-166$. 


\section{Zadania dydaktyczne}

W roku akademickim 1971/1972 rektorzy wyższych uczelni otrzymali z Ministerstwa Oświaty i Szkolnictwa Wyższego pismo w sprawie wytycznych programowych w zakresie przysposobienia bibliotecznego i informacji naukowej dla studentów szkół wyższych. W związku z tym pojawiły się w programach nauczania przedmioty: przysposobienie biblioteczne oraz podstawy informacji naukowej.

W Akademii Ekonomicznej przysposobienie biblioteczne prowadzone było w ramach kursu adaptacyjnego lub w pierwszych tygodniach roku akademickiego. Liczba godzin zajęć ulegała zmianom. W różnych latach był to: dwugodzinny wykład, dwugodzinny wykład oraz cztery godziny ćwiczeń lub sześć godzin ćwiczeń bez wykładu. Zajęcia z informacji naukowej prowadzone były dla studentów pierwszego roku w formie ćwiczeń przez cały semestr w wymiarze jednej godziny tygodniowo. Po 1980 roku przedmiot ten prowadzony był tylko dla studentów Wydziału Inżynieryjno-Ekonomicznego Przemysłu ${ }^{16}$. Spowodowane to było protestami studentów na początku lat osiemdziesiątych przeciwko zbytniemu obciążeniu ich zajęciami obowiązkowymi ${ }^{17}$. W ramach dydaktyki bibliotecznej Biblioteka organizowała w miesiącach wakacyjnych praktyki zawodowe dla studentów bibliotekoznawstwa Uniwersytetu Wrocławskiego oraz Studium Bibliotekarskiego i Kulturalno-Oświatowego we Wrocławiu, sporadyczne praktyki zawodowe (zwane dyplomowymi) dla absolwentów Uczelni oraz szkolenia dla różnych grup użytkowników ${ }^{18}$.

\section{Zadania naukowe}

W 1969 roku ukazały się w „Rocznikach Bibliotecznych” (1969, z. 1-2) dwa teksty bibliotekarzy poruszające sprawę pomocy biblioteki w kształceniu studentów zaocznych: Działalność informacyjna biblioteki na rzecz studentów zaocznych (Jolanta Marcinkowska) oraz sprawozdanie z sesji Stowarzyszenia Bibliotekarzy Polskich w dniach 25-26 października 1968 roku we Wrocławiu, podczas której omawiano to zagadnienie. Współautorką sprawozdania była Halina Pabisz (Sesja Stowarzyszenia Bibliotekarzy Polskich). Poza tym bibliotekarze brali udział w konferencjach poruszających problemy bibliotek wyższych uczelni ekonomicznych. Na sesji naukowej pod nazwą Organizacja informacji naukowej w zespole bibliotek specjalnych (na przykladzie polskich bibliotek ekonomicznych) w Poznaniu w 1977 roku bibliotekarze wygłosili dwa referaty: Założenia do polityki

16 B. Chrapczyńska, M. Świrad, op. cit., s. 156, 160-161.

17 J. Marcinkowska, B. Sobala, Organizacja działalności dydaktycznej biblioteki naukowej specjalnej, [w:] Udziat biblioteki uczelnianej w procesie dydaktyczno-wychowawczym szkoty wyzszej (na przyktadach bibliotek uczelni ekonomicznych), red. J. Sójka, Poznań 1985, s. 6.

18 B. Tichy, op. cit., s. 164-165. 
gromadzenia dokumentów w sieci bibliotek głównych wyższych szkót ekonomicznych (Wilhelm Michniewicz) oraz Obstuga informacyjna badań prowadzonych w wyższych uczelniach ekonomicznych (Jolanta Marcinkowska, Barbara Sobala), które wpisywały się w ogólnopolską dyskusję nad projektem SINTO, przygotowywanie koncepcji Krajowego Systemu Informacyjnego Nauk Społecznych (KSINS) i opracowywanie projektu planu specjalizacji materiałów bibliotecznych w bibliotekach naukowych. W 1984 roku na V Ogólnopolskiej Naradzie Bibliotek Społeczno-Ekonomicznych Aktualne problemy funkcjonowania zespotu polskich bibliotek społeczno-ekonomicznych w Jachrance dyrektor Biblioteki Julian Fercz wygłosił referat Miejsce Biblioteki Akademii Ekonomicznej we Wroctawiu w zespole polskich bibliotek społeczno-ekonomicznych. W tym samym roku na Międzynarodowym Seminarium Porównawczym Udziat biblioteki uczelnianej w procesie dydaktyczno-wychowawczym szkoty wyższej (na przykładach bibliotek uczelni ekonomicznych) w Poznaniu Jolanta Marcinkowska i Barbara Sobala przedstawiły komunikat Organizacja działalności dydaktycznej biblioteki naukowej specjalnej, nawiązując także do doświadczeń swojej macierzystej Biblioteki. Zmiany w zakresie opracowania rzeczowego zaprezentowane zostały przez bibliotekarzy podczas VI Ogólnopolskiej Narady Bibliotek Społeczno-Ekonomicznych Systemy klasyfikacyjne stosowane w zespole polskich bibliotek społeczno-ekonomicznych w Jachrance w 1986 roku. Bibliotekarze wygłosili wtedy dwa referaty: Przeglad systemów klasyfikacyjnych stosowanych w polskich bibliotekach spoteczno-ekonomicznych (Jolanta Marcinkowska, Barbara Sobala, Zbigniew Stankiewicz) oraz Języki informacyjno-wyszukiwawcze w Bibliotece Akademii Ekonomicznej we Wroctawiu (Zbigniew Stankiewicz).

Tematyka publikacji dotyczyła potrzeb użytkowników biblioteki, dydaktyki bibliotecznej, informacji naukowej, systemów klasyfikacji oraz współpracy bibliotek społeczno-ekonomicznych. Pracownicy Biblioteki publikowali także artykuły $\mathrm{z}$ dziedziny filozofii (Bartłomiej Nowotarski) oraz informatyki (Jacek Korta) ${ }^{19}$.

\section{Transformacja ustrojowa i gospodarcza. Komputeryzacja Biblioteki (1990-2005)}

Po 1989 roku nastąpiła w Uczelni rekonstrukcja planów i programów dydaktycznych. Usunięto ekonomię polityczną kapitalizmu i socjalizmu i wprowadzono makro- i mikroekonomię. Zmieniono treści wykładów z polityki ekonomicznej, filozofii, historii myśli ekonomicznej, socjologii i nauki o polityce. Poszerzono zajęcia z informatyki, nauki o zarządzaniu i marketingu. Wprowadzono nowe kierunki: finanse i bankowość oraz zarządzanie i marketing ${ }^{20}$.

19 J. Kasprzyk-Machata, M. Zgorzelska, op. cit., s. 197, 199-201, 205, 207.

20 Księa 60-lecia Akademii Ekonomicznej im. Oskara Langego we Wrocławiu..., s. 250-251. 


\section{Zadania usługowe}

W związku z radykalnymi zmianami w programie studiów Biblioteka stanęła przed koniecznością wymiany księgozbioru. Dokonano ogromnej selekcji, usuwając ze zbiorów podręczniki uznane za nieprzydatne i zaczęto gromadzić zgodne $\mathrm{z}$ nowym programem.

W 1993 roku rozpoczęto komputeryzację Biblioteki. Zakupiono system Lech-BMS pracujący w sieci lokalnej, a w 1996 roku zintegrowany system Prolib z modułami: gromadzenie, wydawnictwa zwarte, wydawnictwa ciągłe, wypożyczalnia, katalog OPAC, administrator ${ }^{21}$. Obok dokumentów w wersji tradycyjnej rozpoczęto gromadzenie dokumentów elektronicznych (między innymi baz danych zawierających publikacje naukowe dostępne online). Nastąpiła stopniowa likwidacja katalogów kartkowych i tworzenie katalogu komputerowego. Zapisy czytelników, zamawianie i rejestracja wypożyczeń odbywały się komputerowo. Oddział Informacji Naukowej organizował dostęp do baz danych utworzonych przez Oddział oraz zakupionych przez Bibliotekę na nośnikach elektronicznych (dyskietki, płyty CD) na komputerach w czytelni Oddziału. Do 2000 roku wydawał informatory o Bibliotece i Bibliografie publikacji pracowników [...] w wersji tradycyjnej, ale od 2001 roku bibliografia ta sporządzana była w wersji komputerowej online. Powstała strona WWW, będąca narzędziem informacji o Bibliotece i jej zasobach, jej promocji i formą kontaktu z czytelnikami. Komunikacja z czytelnikami odbywała się za pomocą poczty elektronicznej, czatu, komunikatorów ${ }^{22}$.

\section{Zadania dydaktyczne}

Po 1995 roku zdecydowano się zawiesić prowadzenie zajęć dydaktycznych dla studentów ze względu na konieczność wypracowania nowej formuły zajęć, uwzględniającej nowe technologie informacyjne. Na spotkaniu Rady Bibliotecznej w listopadzie 2005 roku omówiono kwestię wprowadzenia na nowo do programów studiów przedmiotu obejmującego te zagadnienia ${ }^{23}$.

Kontynuowane były praktyki zawodowe dla studentów bibliotekoznawstwa Uniwersytetu Wrocławskiego. Nowością stały się dwutygodniowe praktyki zawodowe dla pracowników innych bibliotek naukowych Wrocławia i regionu jako warunek awansu na stanowisko starszego bibliotekarza i kustosza ${ }^{24}$.

${ }^{21}$ M. Świrad, Komputeryzacja Biblioteki - doświadczenia i wnioski, [w:] Ewolucja procesów bibliotecznych na tle dziejów Biblioteki Głównej Akademii Ekonomicznej we Wrocławiu..., s. $47-48$.

22 B. Tichy, op. cit., s. 166-170.

23 B. Chrapczyńska, M. Świrad, op. cit., s. 161.

24 Zarządzenie Ministra Edukacji Narodowej w sprawie określenia kwalifikacji zawodowych, jakie powinna posiadać osoba zatrudniona na stanowisku kustosza bibliotecznego, starszego bibliotekarza i starszego dokumentalisty, M.P. 1991, nr 36, poz. 266, par. 2, pkt 2, par. 3, pkt 2. 


\section{Zadania naukowe}

Po 1990 roku ukazały się trzy publikacje, z których każda była wspólnym wysiłkiem pracowników Oddziału Opracowania Rzeczowego Zbiorów: Janiny Pietraszkiewicz, Zbigniewa Stankiewicza i Urszuli Żmijewskiej. Były to: artykuł O niektórych problemach budowy stownika haset przedmiotowych, opublikowany w „Aktualnych Problemach Informacji i Dokumentacji” (1990, nr 3), Stownik katalogu przedmiotowego (Wrocław 1991) i Stownik języka informacyjno-wyszukiwawczego biblioteki społeczno-ekonomicznej (Wrocław 1997). Prezentowały one wyniki prac nad prowadzonym od 1980 roku katalogiem przedmiotowym i słownikiem haseł przedmiotowych.

W 2002 roku w Gdańsku na konferencji Infobazy '2002. Bazy danych dla nauki Małgorzata Świrad wygłosiła referat Swobodny dostęp do katalogów i wypożyczeń za pośrednictwem Internetu. Doświadczenia $i$ wnioski. Przedstawione w nim zostały pierwsze doświadczenia Biblioteki związane z wdrażaniem i eksploatacją systemów elektronicznych wypożyczeń ${ }^{25}$.

\section{Budowa nowego gmachu (2006-2010)}

Warunki lokalowe, w których funkcjonowała Biblioteka od 1954 roku, okazały się niewystarczające i niedostosowane do wymagań stawianych bibliotekom naukowym na początku XXI wieku. Niemożliwe było zwiększenie dostępu do zasobów informacyjnych dla szerszego kręgu użytkowników czy wolnego dostępu do zbiorów tradycyjnych. Zdecydowano się zatem na budowę nowego gmachu Biblioteki. W tworzeniu projektu nowego budynku uczestniczyli wszyscy bibliotekarze. Główne decyzje podejmowała kadra kierownicza Biblioteki, współpracująca z architektem i firmą budowlaną ${ }^{26}$. Stworzono zespół zadaniowy do opracowania i wdrożenia klasyfikacji księgozbioru na Strefę Wolnego Dostępu. Przed przeniesieniem księgozbioru każdy egzemplarz zakodowano w systemie RFID ${ }^{27}$.

Powyższe prace były zadaniem specjalnym, realizowanym w bibliotekach raz na wiele lat. Wymagały dodatkowego wysiłku ze strony bibliotekarzy, którzy przez cały okres przygotowawczy obsługiwali czytelników.

25 J. Kasprzyk-Machata, M. Zgorzelska, op. cit., s. 204, 209.

26 B. Żmigrodzka, Udziat bibliotekarzy w procesie tworzenia nowej siedziby biblioteki, [w:] Dolnośląskie Centrum Informacji Naukowej i Ekonomicznej..., s. 136,145.

27 D. Matysiak, Dolnośląskie Centrum Informacji Naukowej i Ekonomicznej nowym miejscem dla księgozbioru bibliotecznego, [w:] Dolnośląskie Centrum Informacji Naukowej i Ekonomicznej - biblioteka otwarta..., s. 175. 


\section{Zadania usługowe}

Nastąpiła likwidacja Oddziału Opracowania Rzeczowego Zbiorów. Utworzono Oddział Opracowania Zbiorów, który rozpoczął opracowanie zbiorów w formacie Marc21 we współpracy z katalogiem centralnym NUKAT. Biblioteka przystąpiła do konsorcjum Dolnośląskiej Biblioteki Cyfrowej. Dzięki pomocy Politechniki Wrocławskiej rozpoczęto dygitalizację kolekcji starych druków.

\section{Zadania dydaktyczne}

Od roku akademickiego 2006/2007 przywrócono do programu studiów zajęcia biblioteczne pod nazwą biblioteczne systemy informacyjne. Celem ich było zapoznanie studentów z funkcjonowaniem biblioteki oraz ćwiczenia w wyszukiwaniu informacji w zakupionych przez Bibliotekę bazach danych. Zajęcia dla studentów wszystkich wydziałów odbywały się na pierwszym roku. Prowadzone były w laboratoriach komputerowych w budynkach Uczelni w małych grupach ${ }^{28}$.

Nastąpiły zmiany w praktykach dla studentów bibliotekoznawstwa. Trwały one już nie miesiąc wakacyjny, lecz określoną liczbę godzin według nowych standardów kształcenia ${ }^{29}$. Kontynuowane były praktyki dla bibliotekarzy z innych bibliotek jako warunek awansu na stanowisko starszego bibliotekarza i kustosza.

\section{Zadania naukowe}

W latach 1947-2006 pracowało w Bibliotece łącznie czternastu bibliotekarzy dyplomowanych. Wskutek decyzji o zmianie pracy i odejść na emeryturę na początku 2007 roku pracował tylko jeden — dyrektor Biblioteki Barbara Żmigrodzka. Nastąpiła konieczność odbudowy tej grupy. W latach 2006-2010 siedmiu bibliotekarzy zdało egzamin na bibliotekarza dyplomowanego. Wzrosła liczba wydanych prac naukowych. Po raz pierwszy w historii Uczelni bibliotekarze stali się autorami monografii poświęconej macierzystej Bibliotece. Była to książka Ewolucja procesów bibliotecznych na tle dziejów Biblioteki Głównej Akademii Ekonomicznej we Wrocławiu (Wrocław 2007), w której opisano

przemiany, jakie zaszły w bibliotekarstwie w ostatnich 60-ciu latach, związane głównie z automatyzacją i komputeryzacją procesów bibliotecznych — od gromadzenia książek i czasopism poczynając, a na ich udostępnianiu kończąc. [...] Przedstawiono najnowsze trendy w bibliotekar-

28 B. Chrapczyńska, M. Świrad, op. cit., s. 162.

29 Rozporządzenie Ministra Nauki i Szkolnictwa Wyższego z dnia 12 lipca 2007 roku w sprawie standardów kształcenia dla poszczególnych kierunków oraz poziomów kształcenia, a także trybu tworzenia i warunków, jakie musi spełniać uczelnia, by prowadzić studia międzykierunkowe oraz makrokierunki, Dz.U. 2007, nr 164, poz. 1166, par. 13, pkt 1. 
stwie: otwarty dostęp do zbiorów, biblioteki cyfrowe, nowoczesne rozwiązania w budownictwie bibliotecznym ${ }^{30}$.

Bibliotekarze brali udział w jedenastu konferencjach, na których wygłosili osiemnaście referatów. Ponadto powstało jedenaście artykułów opublikowanych w naukowych wydawnictwach recenzowanych, w czasopismach fachowych i w czasopismach Uniwersytetu Ekonomicznego. Sporządzono i opublikowano (Słownik pracowników książki polskiej. Suplement III, Warszawa 2010) trzy biogramy dawnych pracowników Biblioteki: A. Kudelskiego, W. Michniewicza, K. Sołtysika ${ }^{31}$.

Treść publikacji w większości dotyczyła zadań usługowych i nawiązywała bezpośrednio do doświadczeń macierzystej biblioteki. Poza tym poruszano następujące problemy: globalizacja, organizacje bibliotekarskie, budownictwo biblioteczne, kultura organizacyjna.

\section{W nowym budynku (2011-2016)}

\section{Zadania usługowe}

We wrześniu 2011 roku Biblioteka rozpoczęła pracę w nowym budynku o powierzchni $8200 \mathrm{~m}^{2}$. Nastąpiły zmiany w strukturze organizacyjnej Biblioteki. Zlikwidowano Oddział Informacji Naukowej, którego zadania przejęły:

— Oddział Udostępniania i Informacji. Sekcja Obsługi Użytkowników w zakresie informacji na temat zbiorów,

— Ośrodek Informacji Ekonomicznej — w zakresie informacji naukowej i informacji ekonomicznej dla pracowników naukowych Uczelni i studentów,

— Czytelnia Europejska — w zakresie informacji na temat Unii Europejskiej,

— Oddział Dokumentacji i Promocji — w zakresie dokumentacji dorobku naukowego pracowników Uczelni, współtworzenia bazy BazEkon, umieszczania publikacji w DBC, dydaktyki bibliotecznej, przygotowania materiałów informacyjnych.

Powstał nowy Oddział Informatyzacji i Zbiorów Elektronicznych zapewniający wsparcie informatyczne innym jednostkom Biblioteki ${ }^{32}$. Rozpoczęto udostępnianie zbiorów na czterech piętrach Strefy Wolnego Dostępu z otwartymi magazynami i kabinami do indywidualnej nauki, w Czytelni Czasopism Bieżących i Zbiorów Specjalnych, w Czytelni Europejskiej i tradycyjnie — za pośred-

30 Ewolucja procesów bibliotecznych na tle dziejów Biblioteki Głównej Akademii Ekonomicznej we Wrocławiu..., s. IV okładki.

31 J. Kasprzyk-Machata, M. Zgorzelska, op. cit., s. 194-212.

32 M. Świrad, Przeobrażenia w bibliotece jako odpowiedź na zmieniajace się potrzeby obecnych i przyszłych użytkowników, [w:] Dolnoślaskie Centrum Informacji Naukowej i Ekonomicznej-biblioteka otwarta..., s. 27-28. 
nictwem wypożyczalni. Poza tym Biblioteka wzbogaciła się o nowe, przestronne pomieszczenia: sale - wykładową, seminaryjną i wystawową, dwa laboratoria komputerowe, pracownie bibliotekarzy, magazyny kompaktowe ${ }^{33}$.

Korzystne warunki lokalowe Biblioteki przyczyniły się do organizacji różnego rodzaju wydarzeń: wystaw, spotkań autorskich, promocji książek, debat, imprez integracyjnych w środowisku bibliotekarskim, wycieczek. Wzrosła rola Biblioteki jako „trzeciego miejsca”, sprzyjającego zacieśnieniu więzi między biblioteką a użytkownikiem ${ }^{34}$.

\section{Zadania dydaktyczne}

Od 2011 roku w ramach edukacji informacyjnej rozpoczęto prowadzenie zajęć dla studentów w salach laboratoryjnych Biblioteki, a także wykorzystywanie e-Kursu. Liczbę godzin zajęć regulowały uchwały Senatu Uczelni.

Uchwałą Senatu z 27 stycznia 2011 roku ustalono liczbę godzin zajęć bibliotecznych na osiemnaście, do wykorzystania na pierwszym i drugim roku studiów. W praktyce zajęcia odbywały się w dwu semestrach. Ponadto dla studiów licencjackich niestacjonarnych i magisterskich (stacjonarnych i niestacjonarnych) Wydziału Nauk Ekonomicznych ustalono cztery godziny zajęć. Na Wydziale Zarządzania, Informatyki i Finansów ustalono trzy godziny zajęć laboratoryjnych dla studiów niestacjonarnych. Na powyższych wydziałach prowadzone były także zajęcia w języku angielskim dla grup anglojęzycznych z wykorzystaniem e-Kursu w tym języku. Dla studiów doktoranckich ustalono cztery godziny zajęć w laboratorium i e-Kurs.

Uchwałą Senatu z dnia 28 maja 2015 roku ustalono sześć godzin zajęć bibliotecznych dla studiów stacjonarnych pierwszego i drugiego stopnia. Obowiązuje ona od roku akademickiego 2015/2016. Warunkiem otrzymania zaliczenia jest aktywny udział w zajęciach oraz zaliczenie trzech pierwszych modułów e-Kursu ${ }^{35}$.

Kontynuowane były praktyki dla studentów bibliotekoznawstwa oraz bibliotekarzy z innych bibliotek jako warunek awansu na stanowisko starszego bibliotekarza i kustosza.

\section{Zadania naukowe}

W latach 2011-2016 trzy osoby zdały egzamin na bibliotekarza dyplomowanego, a jedna otrzymała ten tytuł na podstawie oceny dorobku.

33 Biblioteka Główna Uniwersytetu Ekonomicznego we Wrocławiu, http://www.bg.ue.wroc. pl/o_nas/15678/o_dcinie.html [dostęp: 20.02.2018].

34 P. Mildner, M. Zgorzelska, Kształtowanie więzi czytelnik-biblioteka, [w:] Biblioteka na miare..., s. 32-40.

35 B. Chrapczyńska, M. Świrad, op. cit., s. 162-164. 
W okresie tym powstały dwie kolejne monografie o Bibliotece. Pierwsza z nich to Dolnoślaskie Centrum Informacji Naukowej i Ekonomicznej — biblioteka otwarta (2011). Zaprezentowano w niej

zmiany zachodzące we współczesnych bibliotekach naukowych związane z przekształcaniem tradycyjnych placówek magazynujących zbiory w nowoczesne centra informacyjne $\mathrm{z}$ otwartym dostępem do zasobów i usług dopasowanych do oczekiwań społeczeństwa informacyjnego oraz [...] doświadczenia nabyte $\mathrm{w}$ trakcie powstawania nowej siedziby swojej biblioteki ${ }^{36}$.

Druga to Biblioteka na miarę: przestrzeń, zasoby, ustugi (2016). Przedstawiono w niej

różne aspekty funkcjonowania nowoczesnej biblioteki, zaczynając od samej powierzchni, [...] przez budowę trwałych więzi z czytelnikami, aż po próbę odpowiedzi na pytanie, jakie środki komunikacji z biblioteką wybierają użytkownicy ${ }^{37}$.

Bibliotekarze brali udział w dwunastu konferencjach, na których wygłosili siedemnaście referatów. Powstało także dwadzieścia dziewięć artykułów, w tym pięć z ekonomii (Dawid Kościewicz). Ukazały się w naukowych wydawnictwach recenzowanych, czasopismach fachowych oraz w czasopiśmie uczelnianym ${ }^{38}$.

\section{Zakończenie}

Zadaniem bibliotek uczelni wyższych było, jest i nadal będzie gromadzenie, opracowywanie, udostępnianie zbiorów, prowadzenie prac z zakresu informacji naukowej, prowadzenie zajęć dydaktycznych, praca naukowa. Zadania się nie zmieniły, modyfikacji zaś uległy sposoby i narzędzia ich realizacji. Najważniejszymi czynnikami zmian były:

- przepisy prawne (ustawy, zarządzenia, uchwały senatu),

— potrzeby użytkowników,

- programy studiów,

— warunki lokalowe,

— rozwój technologii informacyjnych.

Należy podkreślić czynnik ludzki, a więc zaangażowanie samych bibliotekarzy w codzienną pracę i stałe podnoszenie kwalifikacji zawodowych. Cały zespół wykonuje zadania usługowe. Bibliotekarze dyplomowani oraz bibliotekarze służby bibliotecznej legitymujący się wyższym wykształceniem bibliotekoznawczym realizują dodatkowo zadania dydaktyczne, w trakcie których przekazują

36 Dolnośląskie Centrum Informacji Naukowej i Ekonomicznej - biblioteka otwarta..., s. IV okładki.

37 Wstęp, [w:] Biblioteka na miarę..., s. 9.

38 M. Zgorzelska (oprac.), Publikacje pracowników Biblioteki, [w:] Biblioteka na miarę..., s. 213-218; Biblioteka Główna Uniwersytetu Ekonomicznego we Wrocławiu, Repozytorium, http://wir.bg.ue.wroc.pl/index.seam [dostęp: 8.02.2018]. 
użytkownikom wiedzę o bibliotece i pomagają zdobyć umiejętności w wyszukiwaniu informacji w różnych źródłach. Bibliotekarze dyplomowani oraz chętni bibliotekarze służby bibliotecznej z tytułem magistra biorą także udział w pracy naukowej, której celem jest utrwalenie wiedzy o działalności Biblioteki w różnych okresach jej istnienia i przekazywanie jej następnym pokoleniom odbiorców.

\section{Bibliografia}

Biblioteka Główna Uniwersytetu Ekonomicznego we Wrocławiu, http://www.bg.ue.wroc.pl/o_nas/15678/o_dcinie.html [dostęp: 20.02.2018].

Biblioteka Główna Uniwersytetu Ekonomicznego we Wrocławiu, Repozytorium, http://wir.bg.ue. wroc.pl/index.seam [dostęp: 8.02.2018].

Biblioteka na miarę: przestrzeń, zasoby, ustugi, red. M. Świrad, B. Żmigrodzka, Wydawnictwo Uniwersytetu Ekonomicznego we Wrocławiu, Wrocław 2016.

Chrapczyńska B., Świrad M., Edukacja informacyjna w bibliotece akademickiej, [w:] Biblioteka na miarę: przestrzeń, zasoby, usługi, red. M. Świrad, B. Żmigrodzka, Wydawnictwo Uniwersytetu Ekonomicznego we Wrocławiu, Wrocław 2016, s. 153-168.

Dolnoślaskie Centrum Informacji Naukowej i Ekonomicznej - biblioteka otwarta, red. B. Żmigrodzka, Wydawnictwo Uniwersytetu Ekonomicznego we Wrocławiu, Wrocław 2011.

Ewolucja procesów bibliotecznych na tle dziejów Biblioteki Głównej Akademii Ekonomicznej we Wrocławiu, red. B. Żmigrodzka, Wydawnictwo Akademii Ekonomicznej im. Oskara Langego we Wrocławiu, Wrocław 2007.

Kasprzyk-Machata J., Zgorzelska M., Publikacje pracowników Biblioteki Głównej Uniwersytetu Ekonomicznego we Wroctawiu, [w:] Dolnoślaskie Centrum Informacji Naukowej i Ekonomicznej - biblioteka otwarta, red. B. Żmigrodzka, Wydawnictwo Uniwersytetu Ekonomicznego we Wrocławiu, Wrocław 2011, s. 189-213.

Księga 60-lecia Akademii Ekonomicznej im. Oskara Langego we Wrocławiu, red. J. Chumiński, Wydawnictwo Akademii Ekonomicznej im. Oskara Langego we Wrocławiu, Wrocław 2007.

Kudelski A., Biblioteka Główna Wyższej Szkoły Ekonomicznej we Wrocławiu, [w:] Zarys rozwoju wrocławskiej Wyższej Szkoty Ekonomicznej w latach 1946-1964, red. Z. Hellwig, [s.n.], Wrocław 1965, s. 115-124.

Kudelski A., Materiały do kroniki bibliotek wyższych szkół ekonomicznych za lata 1945-1963, „Roczniki Biblioteczne” 1964, z. 1-2, s. 319-324.

Marcinkowska J., Sobala B., Organizacja działalności dydaktycznej biblioteki naukowej specjalnej, [w:] Udziat biblioteki uczelnianej w procesie dydaktyczno-wychowawczym szkoty wyższej (na przykładach bibliotek uczelni ekonomicznych), red. J. Sójka, Akademia Ekonomiczna. Biblioteka Główna, Poznań 1985, s. 1-8.

Matysiak D., Dolnośląskie Centrum Informacji Naukowej i Ekonomicznej nowym miejscem dla ksieggozbioru bibliotecznego, [w:] Dolnoślaskie Centrum Informacji Naukowej i Ekonomicznej - biblioteka otwarta, red. B. Żmigrodzka, Wydawnictwo Uniwersytetu Ekonomicznego we Wrocławiu, Wrocław 2011, s. 167-188.

Mildner P., Zgorzelska M., Ksztaltowanie więzi czytelnik-biblioteka, [w:] Biblioteka na miarę: przestrzeń, zasoby, ustugi, red. M. Świrad, B. Żmigrodzka, Wydawnictwo Uniwersytetu Ekonomicznego we Wrocławiu, Wrocław 2016, s. 27-50.

Świrad M., Komputeryzacja Biblioteki - doświadczenia i wnioski, [w:] Ewolucja procesów bibliotecznych na tle dziejów Biblioteki Głównej Akademii Ekonomicznej we Wrocławiu, red. 
B. Żmigrodzka, Wydawnictwo Akademii Ekonomicznej im. Oskara Langego we Wrocławiu, Wrocław 2007, s. 47-53.

Świrad M., Przeobrażenia $w$ bibliotece jako odpowiedź na zmieniajace się potrzeby obecnych i przysztych użytkowników, [w:] Dolnoślaskie Centrum Informacji Naukowej i Ekonomicznej - biblioteka otwarta, red. B. Żmigrodzka, Wydawnictwo Uniwersytetu Ekonomicznego we Wrocławiu, Wrocław 2011, s. 11-30.

Tichy B., Ustugi Oddziału Informacji Naukowej w latach 1962-2006, [w:] Ewolucja procesów bibliotecznych na tle dziejów Biblioteki Głównej Akademii Ekonomicznej we Wrocławiu, red. B. Żmigrodzka, Wydawnictwo Akademii Ekonomicznej im. Oskara Langego we Wrocławiu, Wrocław 2007, s. 161-174.

Zagrajek E., Żmigrodzka B., Biblioteka Główna 1947-1982, Akademia Ekonomiczna, Wrocław 1983. Zgorzelska M. (oprac.), Publikacje pracowników Biblioteki, [w:] Biblioteka na miarę: przestrzeń, zasoby, ustugi, red. M. Świrad, B. Żmigrodzka, Wydawnictwo Uniwersytetu Ekonomicznego we Wrocławiu, Wrocław 2016, s. 213-218.

Żmigrodzka B., Udział bibliotekarzy w procesie tworzenia nowej siedziby biblioteki, [w:] Dolnoślaskie Centrum Informacji Naukowej i Ekonomicznej - biblioteka otwarta, red. B. Żmigrodzka, Wydawnictwo Uniwersytetu Ekonomicznego we Wrocławiu, Wrocław 2011, s. 136-166.

Żmijewska U., Opracowanie rzeczowe zbiorów, [w:] Ewolucja procesów bibliotecznych na tle dziejów Biblioteki Głównej Akademii Ekonomicznej we Wrocławiu, red. B. Żmigrodzka, Wydawnictwo Akademii Ekonomicznej im. Oskara Langego we Wrocławiu, Wrocław 2007, s. 88-102.

\title{
Akty prawne
}

Rozporządzenie Ministra Nauki i Szkolnictwa Wyższego z dnia 12 lipca 2007 roku w sprawie standardów kształcenia dla poszczególnych kierunków oraz poziomów kształcenia, a także trybu tworzenia i warunków, jakie musi spełniać uczelnia, by prowadzić studia międzykierunkowe oraz makrokierunki, Dz.U. 2007, nr 164, poz. 1166.

Uchwała nr 477 Rady Ministrów z dnia 4 czerwca 1952 roku w sprawie wzorcowego statutu szkoły wyższej, M.P. 1952, nr 57, poz. 883.

Ustawa z dnia 5 listopada 1958 roku o szkołach wyższych, Dz.U. 1958, nr 68, poz. 336.

Ustawa z dnia 9 kwietnia 1968 roku o bibliotekach, Dz.U. 1968, nr 12, poz. 63.

Ustawa z dnia 4 maja 1982 roku o szkolnictwie wyższym, Dz.U. 1982, nr 14, poz. 113.

Ustawa z dnia 12 września 1990 roku o szkolnictwie wyższym, Dz.U. 1990, nr 65, poz. 385.

Zarządzenie Ministra Edukacji Narodowej w sprawie określenia kwalifikacji zawodowych, jakie powinna posiadać osoba zatrudniona na stanowisku kustosza bibliotecznego, starszego bibliotekarza i starszego dokumentalisty, M.P. 1991, nr 36, poz. 266.

\section{Changes in the rules of realization of tasks in the Main Library of the Wrocław University of Economics in the years 1947-2016}

\author{
Summary
}

The article presents changes which have taken place in the principles of realization of tasks of the library within the years 1947-2016. The most important tasks of a scientific library are: the organization of bibliographic and information workshops, didactics and scientific research activities. The 
fulfilling of certain tasks in five following periods of the library's existence has been analyzed based on publications of the library staff. The tasks themselves have not been changed, what has been altered, are the methods and tools of their realization. The conclusion points at the causes of change: the law, needs of users, modification of didactic programs, locum conditions, development of IT technologies and the commitment of librarians.

KEYWORDS: Main Library of the Wrocław University of Economics, academic libraries, tasks of academic libraries 